\title{
Temperature and seasonal occurrence patterns of 30 dominant phytoplankton species in Narragansett Bay over a 22-year period (1959-1980)
}

\author{
Deneb Karentz* and Theodore J. Smayda**
}

Graduate School of Oceanography, University of Rhode Island, Kingston, Rhode Island 02881, USA

\begin{abstract}
A 22-yr series of quantitative, weekly phytoplankton samples collected in Narragansett Bay, RI (USA) established patterns in temporal occurrence and abundance of 138 taxa. Patterns exhibited by the 30 species most abundant numerically were evaluated by principal components analysis. Their seasonal occurrence ordinated along seasonal gradients which corresponded to annual trends in water temperature and, secondarily, light intensity. Ordination along an in situ temperature gradient was generally consistent with the expected influence of temperature on cell division rates, based on laboratory experiments. Several lines of evidence contest, however, that their succession in Narragansett Bay was determined primarily by temperature: annual field maxima of the individual species occurred at mean temperatures $\left(22 \mathrm{yr}\right.$ data set) $3^{\circ}$ to $14^{\circ} \mathrm{C}$ lower than their laboratory growth optima; several species usually disappeared in situ at temperatures below their laboratory optima; annual maxima for the various species occurred over a wide temperature range, with the minimum and maximum range being $7^{\circ}$ and $>23^{\circ} \mathrm{C}$, respectively; temperature accompanying the first detectable annual occurrence of the species ( = entry temperature) varied considerably between years; and resting spores of winter species apparently do not survive summer bottom water temperatures in Narragansett Bay. These observations raise a number of questions as to the actual role of temperature in regulating phytoplankton species succession in Narragansett Bay. Other environmental factors (biotic and/or abiotic) may exert a more direct influence on this ecological process, or through interaction with temperature.
\end{abstract}

\section{INTRODUCTION}

Continuous temporal change in the taxonomic structure of phytoplankton communities is one of their most obvious and well-documented characteristics (Smayda, 1980). Annual successional patterns are particularly well-established for temperate bays and estuaries, where changes in species composition are sometimes accompanied by significant seasonal oscillations in the physical-chemical aspects of the plankton environment (Gran and Braarud, 1935; Smayda, 1957, 1980; Patten et al., 1963; Carpenter, 1971; Garrison, 1979; Watling et al., 1979, and others). Description

- Present address: Laboratory of Radiobiology and Environmental Health, University of California, San Francisco, California 94143, USA

- Addressee for reprint requests and elucidation of phytoplankton species succession are primary objectives in the study of phytoplankton ecology. This requires both field and laboratory investigation of the biotic and abiotic factors which may regulate and/or modify this process (e.g. Smayda, 1980). The patterns of phytoplankton species occurrence in Narragansett Bay, Rhode Island over a 22-yr period are described and evaluated in this paper. Our major objectives are to identify seasonal trends in the occurrence of individual species, to examine temporal associations between species, and to evaluate the extent to which temperature and irradiance influenced such events.

\section{METHODS}

Since 1959, weekly surface water samples have been collected in lower Narragansett Bay, Rhode Island 
(USA) at a station (II) located at $41^{\circ} 34^{\prime} \mathrm{N} 71^{\circ} 23^{\prime} \mathrm{W}$ (Pratt, 1959, 1965; Smayda, 1973). This region of the bay is well-mixed year-round, and more strongly influenced by marine than fresh water. The data considered here extend from Jan 1959 through Dec 1980. Samples were not collected from Jul through Dec 1963, in Jun and Jul 1977, nor in Mar and Apr 1978. Otherwise, missing data occurred randomly throughout the sampling period. The data set of 1,000 weekly samples represents $87 \%$ of the possible total, and consists of species counts and concurrent measurements of incident light intensity and water temperature. Live samples were examined in a Sedgwick-Rafter chamber for species identification and enumeration of cells. Water temperatures were recorded in the field and incident light intensity levels (weekly mean ly $\mathrm{d}^{-1}$ ) were obtained from Eppley Laboratories in Newport, RI (located $9 \mathrm{~km}$ from the study area).

Identification of species associations was facilitated by applying a principal components analysis (PCA) to a subset of data which comprised the 30 most abundant species. Total abundance for each species was obtained by summation of their cell numbers per $\mathrm{ml}$ values from each sample date. Reduction in the rank of the data matrix to $\mathrm{n}=30$ species eliminated the large proportion of zeros (i.e. non-occurrences) associated with less common species, and focused the analysis on the temporal variation of numerically dominant species in the bay. Prior to statistical analysis, all cell counts were transformed $\left(\mathrm{x}^{*}\right)$ as follows:

$$
\mathrm{x}^{*}=\log _{\mathrm{e}}(\mathrm{x}+1)
$$

where $\mathrm{x}=$ number of cells per $\mathrm{ml}$ for a given species on a given sample date. Log-transformed data were used to reduce the degree of bias associated with species which had higher cell densities, while still preserving the relative differences in magnitude of occurrence (Allen and Koonce, 1973).

The PCA was performed on the species correlation matrix using program BMDP4M of the Biomedical Computer Programs P-Series (Dixon and Brown, 1979). This analysis, an ordination technique, is directed at summarizing numerical variation within a data set (Cooley and Lohnes, 1971; Cassie, 1972). To construct a simple geometric model of this study, each of the 30 species (variables) may be considered as a single point projected into a multidimensional space defined by the 1,000 sample dates (i.e. cases) (Allen and Skagen, 1973). The analysis begins with the generation of principal component l (PC1), a vector calculated to maximize the variation among the species points. Successive vectors are generated such that each vector maximizes the residual variance (i.e. that not accounted for by preceding vectors). The proportion of the total var- iance accounted for by each PC is determined by the eigenvalues of the correlation matrix. The correlation matrix tends to emphasize the occurrence of the less abundant species, in contrast to usage of a covariance matrix. The PCA considers both the period and magnitude of occurrence of each species, and was therefore applied to assess the temporal associations among the 30 numerically dominant phytoplankton species in Narragansett Bay. Program BMDP4R was also used to regress light and temperature data on the principal components generated through the analysis of the species matrix.

\section{RESULTS}

\section{Species}

A total of 138 phytoplankton taxa representing 55 genera (excluding micro-flagellates) were identified from Narragansett Bay. These included 84 diatom and 30 dinoflagellate species. Frequency of occurrence, total abundance and maximum recorded values of the 49 most abundant taxa are listed in Table 1 . The criterion for selection of a given species into this category was that its cumulative abundance in the 1,000 samples exceeded 1,000 cells $\mathrm{ml}^{-1}$.

The diatom Skeletonema costatum was numerically the most abundant species; it occurred in $88 \%$ of the 1,000 samples collected during the 22 -yr period (Fig. 1). Its yearly pattern of maximal occurrence was bimodal; cell densities were highest during late winter-early spring and in mid-summer (Aug), and consistently lowest during Jun and Jul. The highest recorded cell density of $S$. costatum occurred in 1979 $\left(108,750\right.$ cells $\left.\mathrm{ml}^{-1}\right)$. Maximal and minimal mean annual abundance were recorded in $1963(6,233$ cells $\mathrm{ml}^{-1}$ ) and 1965 (954 cells ml ${ }^{-1}$ ), respectively.

Detonula confervacea, the second most abundant species encountered, and Thalassiosira nordenskioeldii, ranked fifth, are characteristic members of the winter phytoplankton assemblages in Narragansett Bay (Fig. 1). Although both species occurred each year between Jan and Mar, their patterns of yearly abundance were dissimilar. D. confervacea exhibited its highest abundances during the early $1960 \mathrm{~s}$; since 1965, cell densities have been lower. T. nordenskioeldii, in contrast, exhibited wide fluctuations in its annual abundance. Peak levels appeared to occur at 5-yr intervals during the 22-yr sampling period.

Asterionella glacialis, numerically the third most abundant species, occurred at various times throughout the year, similar to Skeletonema costatum (Fig. 1). Although highest cell concentrations were recorded in late summer and in winter, A. glacialis exhibited an erratic pattern of yearly abundance. During the first 
Table 1. List of the 49 most abundant species with summation of weekly cell ml-1 values (cum), frequency of occurrence in 1000 samples (fq) and maximum cells $\mathrm{ml}^{-1}$ observed (max)

\begin{tabular}{|c|c|c|c|}
\hline Species & cum & fq & $\max$ \\
\hline Skeletonema costatum (Grev.) Cleve & 2395720 & 876 & 108749 \\
\hline Detonula confervacea (Cleve) Gran & 253971 & 264 & 13298 \\
\hline Asterionella glacialis Castracane & 208471 & 355 & 13129 \\
\hline Olisthodiscus luteus Carter & 138580 & 226 & 31799 \\
\hline Thalassiosira nordenskioeldii Cleve & 133440 & 323 & 8124 \\
\hline Thalassiosira sp. Cleve & 119045 & 352 & 6874 \\
\hline Leptocylindrus minimus Gran & 56635 & 478 & 4951 \\
\hline Leptocylindrus danicus Cleve & 49240 & 279 & 9584 \\
\hline Chaetoceros compressus Lauder & 40859 & 115 & 3302 \\
\hline Rhizosolenia delicatula Cleve & 37638 & 296 & 5448 \\
\hline Rhizosolenia fragilissima Bergon & 29350 & 201 & 12314 \\
\hline Chaetoceros debilis Cleve & 20557 & 82 & 3045 \\
\hline Katodinium rotundatum (Lohmann) Fott & 20254 & 206 & 8749 \\
\hline Prorocentrum redfieldii Bursa & 19800 & 193 & 3199 \\
\hline Chaetoceros curvisetum Cleve & 19353 & 151 & 2295 \\
\hline Thalassionema nitzschioides Hustedt & 17896 & 268 & 1512 \\
\hline Cerataulina pelagica (Cleve) Hendy & 15231 & 120 & 3813 \\
\hline Thalassiosira rotula Meunier & 15065 & 248 & 1458 \\
\hline Chroomonas amphioxeia (Conrad) Butcher & 12722 & 213 & 629 \\
\hline Gymnodinium sp. Stein & 9644 & 399 & 1899 \\
\hline Chaetoceros gracilis Schütt & 9143 & 47 & 1533 \\
\hline Chaetoceros diadema (Ehrenb.) Gran & 9004 & 45 & 2495 \\
\hline Pyramimonas torta Conrad et Kuff & 7676 & 189 & 3444 \\
\hline Scrippsiella trochoidea (Stein) Loeblich & 7519 & 197 & 1351 \\
\hline Chaetoceros tortissima Gran & 7456 & 33 & 2089 \\
\hline Prorocentrum triangulatum Martin & 7062 & 193 & 579 \\
\hline Chaetoceros didymus Ehrenb. & 6655 & 131 & 775 \\
\hline Nitzschia closterium (Ehrenb.) Wm. Smith & 6518 & 297 & 533 \\
\hline Chaetoceros affinis Lauder & 6045 & 58 & 2049 \\
\hline Chaetoceros similis Cleve & 5936 & 96 & 557 \\
\hline Nitzschia seriata Cleve & 5908 & 129 & 557 \\
\hline Thalassiosira decipiens Cleve & 5423 & 91 & 2037 \\
\hline Rhizosolenia setigera Brightwell & 5166 & 268 & 311 \\
\hline Chaetoceros lorenzianus Grunow & 4593 & 68 & 524 \\
\hline Chaetoceros decipiens Cleve & 4489 & 72 & 810 \\
\hline Thalassiosira gravida Cleve & 4263 & 46 & 878 \\
\hline Chaetoceros socialis Lauder & 3691 & 19 & 708 \\
\hline Prorocentrum scutellum Schroder & 3092 & 150 & 434 \\
\hline Thalassiosira pseudonana Hasle et Heimdal & 2967 & 16 & 1194 \\
\hline Chaetoceros subtilis Cleve & 2940 & 60 & 1462 \\
\hline Ditylum brightwelli (T. West) Grunow ex. van Heurck & 2536 & 96 & 536 \\
\hline Unidentified flagellate & 2550 & 33 & 462 \\
\hline Heterocapsa triquetra (Ehrenb.) Stein & 2510 & 118 & 258 \\
\hline Lithodesmium undulatum Ehrenb. & 2299 & 30 & 1065 \\
\hline Cyclotella caspia Grunow & 1782 & 4 & 993 \\
\hline Peridinium sp. Ehrenb. & 1551 & 177 & 216 \\
\hline Phaeocystis pouchetii (Hariot) Lagerh. & 1305 & 48 & 499 \\
\hline Eucampia zoodiacus Ehrenb. & 1286 & 49 & 155 \\
\hline cf. Attheya decora West & 1272 & 69 & 72 \\
\hline
\end{tabular}

$5 \mathrm{yr}$ of this study it was absent in the summer samples; it then appeared in Aug 1964, and in 1965 reached its annual maximum during Aug. It attained extremely high population densities during 1960 and 1968. The interval from 1962 through 1966 was a period of markedly low abundance, followed by very high population densities from 1967 to 1969. Population levels were relatively low in the 1970 s and characterized by annual flucutations.
Olisthodiscus luteus, the most abundant non-diatom and ranked fourth overall, occurred from May through Dec; maximum cell densities occurred during the summer and early fall (Fig. 2). It exhibited a distinct bimodal pattern of occurrence during this period, with maximal abundance in late Jun-early Jul, followed by a secondary peak in Nov (Fig. 3) (see also Tomas, 1980). High concentrations of $O$. luteus usually were accompanied by the lowest cell densities of 


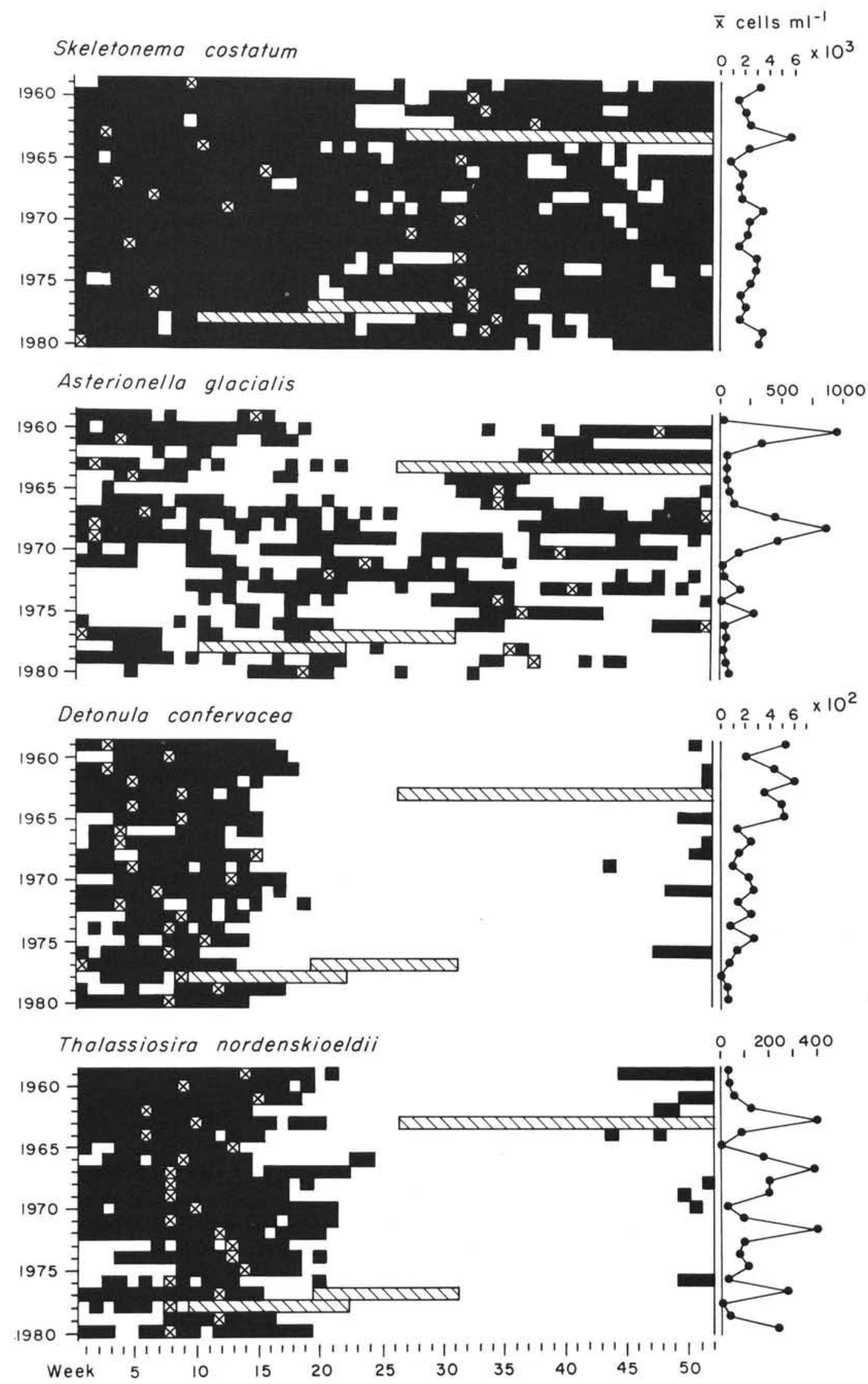

Fig. 1. Occurrence of Skeletonema costatum, Asterionella glacialis, Detonula confervacea and Thalassiossira nordenskioeldii in Narragansett Bay, 1959-1980. X: week of maximum abundance during year. Hatched areas: periods when samples were not collected. Annual mean densities plotted in right margin 


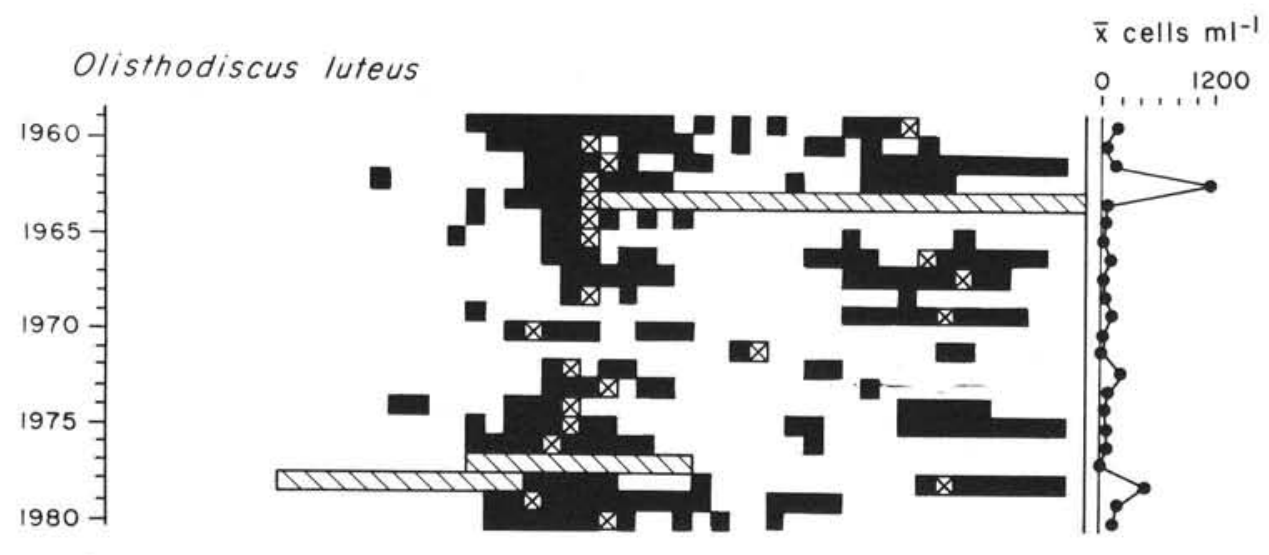

Prorocentrum redfieldii
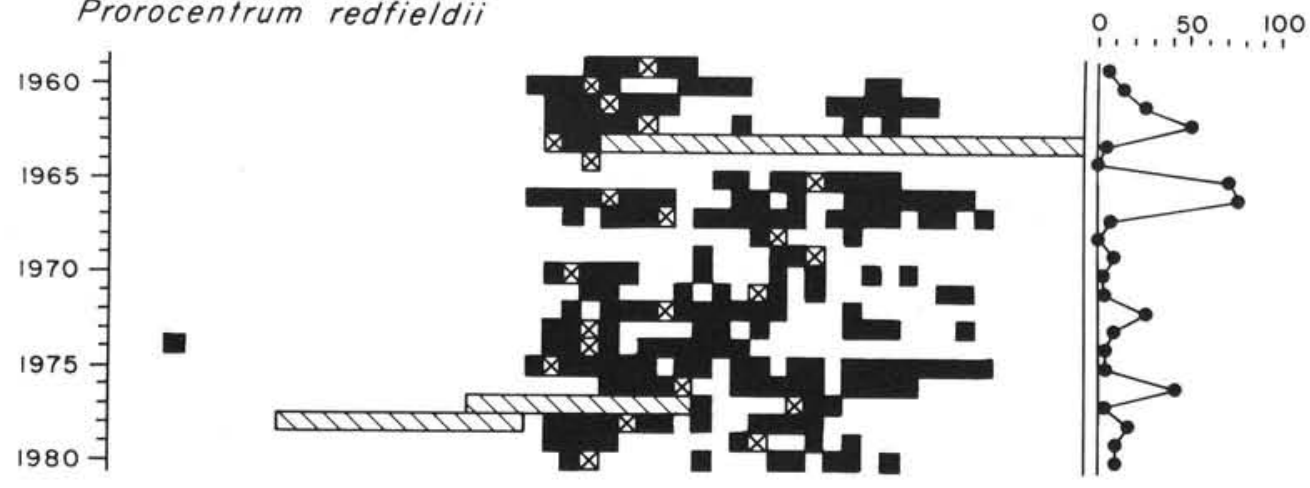

Prorocentrum triangulatum
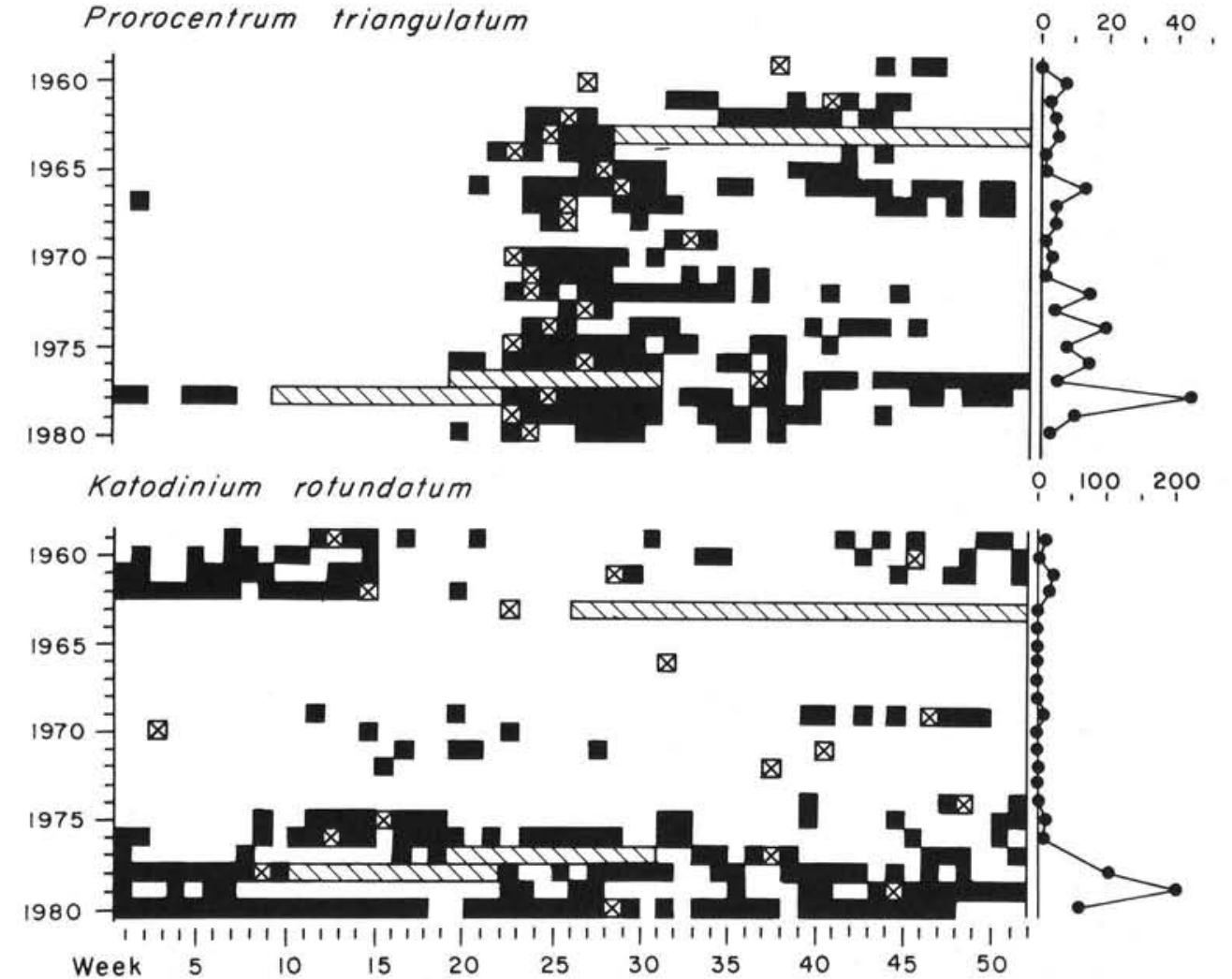

Fig. 2. Occurrence of Olisthodiscus luteus, Massartia (Katodinium) rotundatum, Prorocentrum redfieldii and $P$, triangulatum in Narragansett Bay, 1959-1980. Otherwise, as for legend to Fig. 1 


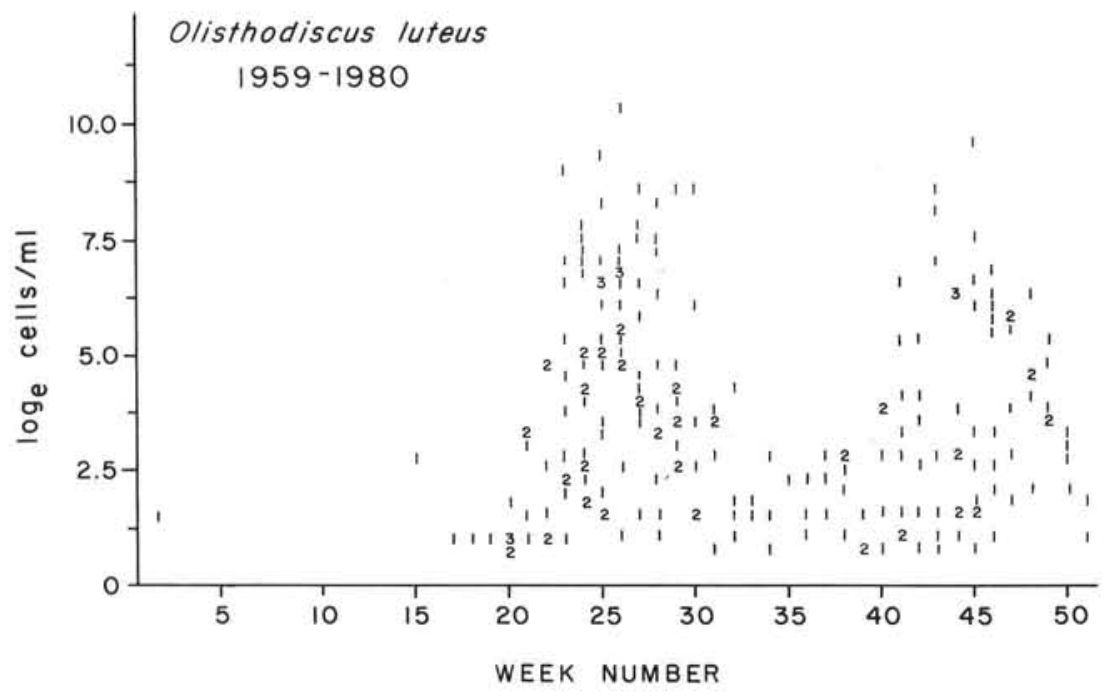

Fig. 3. Weekly cell abundance as $\log _{e}$ of Olisthodiscus luteus during 1959-1980 in Narragansett Bay. Arabic numerals: number of observations at that abundance level for a given week; absences not indicated
Skeletonema costatum. The largest recorded population of Olisthodiscus was observed in $1962(31,800$ cells $\mathrm{ml}^{-1}$ ); cell concentrations have since remained at relatively lower levels.

A small $(\sim 10 \mu \mathrm{m})$ unidentified species of Thalassiosira was ranked sixth in total cell abundance and fifth in frequency of occurrence (Fig. 4). This diatom first appeared in Narragansett Bay in 1967; since 1974 it has exhibited a continual increase in mean annual population density. It usually reaches its annual maximum in summer, although several annual maxima have been recorded during the winter.

Leptocylindrus minimus, ranked seventh in total abundance and the second most frequently encountered species, was present in $48 \%$ of the samples (Fig. 4). It was observed throughout the year, and most frequently reached its annual maximum in spring, with an occasional summer or fall maximum. It exhibited a fair degree of fluctuation in annual mean abundance. 1965,1968 and 1974 were years of very high population density for this species.

Leptocylindrus danicus, ranked eighth in total abundance, was more restricted in its seasonal occurrence than $L$. minimus. Rarely encountered in winter samples (Fig. 4), its yearly maximum usually occurred in May or Jun, occasionally later in the summer. This pattern of annual abundance was similar to that for Thalassiosira nordenskioeldii, for which peaks in yearly mean density occurred at approximately fiveyear intervals.

There were 26 species of Chaetoceros identified during the sampling period, of which 13 are among the 49 most numerically abundant taxa. Nine species were used in the PCA (Table 2). C. compressus had the highest total cell count, but $C$. curvisetum and $C$. didymus were encountered more frequently. C. compressus, $C$. debilis and $C$. diadema had relatively restricted ranges of temporal occurrence. C. compressus was present primarily between Mar and May, except during 1970 when its maximum abundance occurred in Sep. It exhibited its highest abundances in the early 1960s, and was not detected from 1965 to 1968.

Chaetoceros debilis had a similar pattern of occurrence, although it was less common and not recorded for eight years of the study. It usually reached peak abundance in late winter or early spring, with an occasional yearly maximum in the fall. Populations were greatest in the late 1960 s.

Chaetoceros diadema, first observed in 1968, was not present each year. Highest cell densities were recorded in 1968 and 1970; its annual maximum usually occurred in late winter or early spring, similar to Detonula confervacea and Thalassiosira nordenskioeldii.

Chaetoceros didymus was most common during late summer; in several years its annual maximum occurred during the spring (Fig. 5). Its long-term pattern of total annual abundance was similar to those for Thalassiosira nordenskioeldii and Leptocylindrus danicus, which exhibited peaks in cell numbers at 5-yr intervals.

Chaetoceros curvisetum attained its annual maximum in the fall and winter (Fig. 5); its annual maxima were greater during the 1960 s, notably in 1968 , than during the 1970 s.

Ten species of Rhizosolenia were found in Narragansett Bay, but only 3 were quantitatively significant: $R$. delicatula, $R$. fragilissima, $R$. setigera (Fig. 6). $R$. delicatula, observed throughout the year, did not exhibit any obvious consistent pattern in its seasonal abundance. It was encountered more frequently during the first decade of this study, reaching peak abundances from 1966 through 1969, followed by a low 


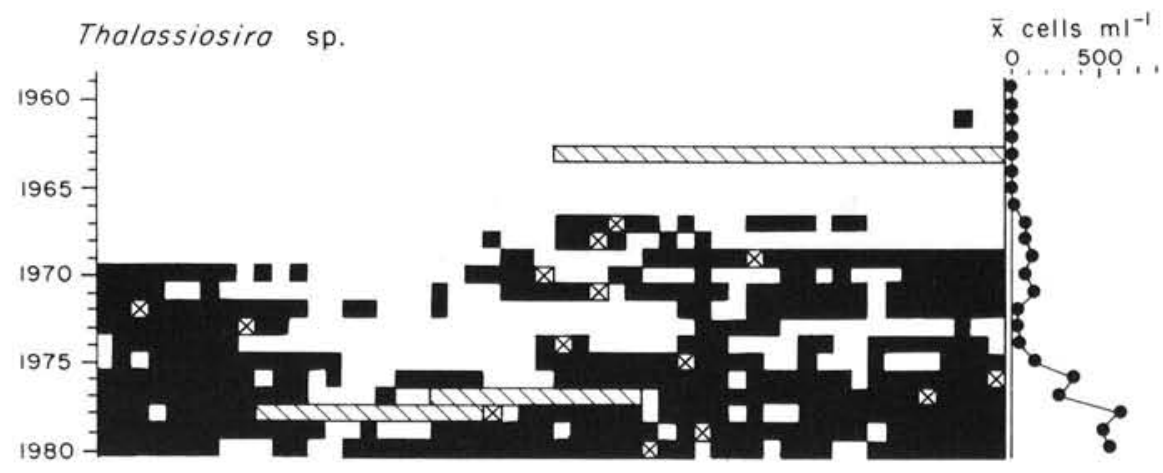

Fig. 4. Occurrence of Thalassiosira sp., Leptocylindrus minimus, L. danicus and Thalassionema nitzschioides in Narragansett Bay, 1959-1980. Otherwise, as for legend to Fig. 1

\section{Leptocylindrus minimus}

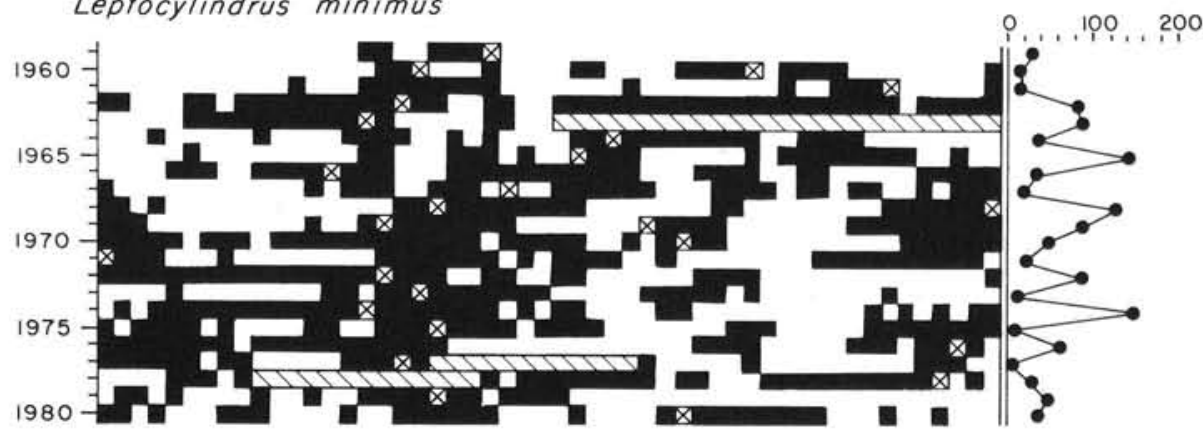

Leptocylindrus danicus

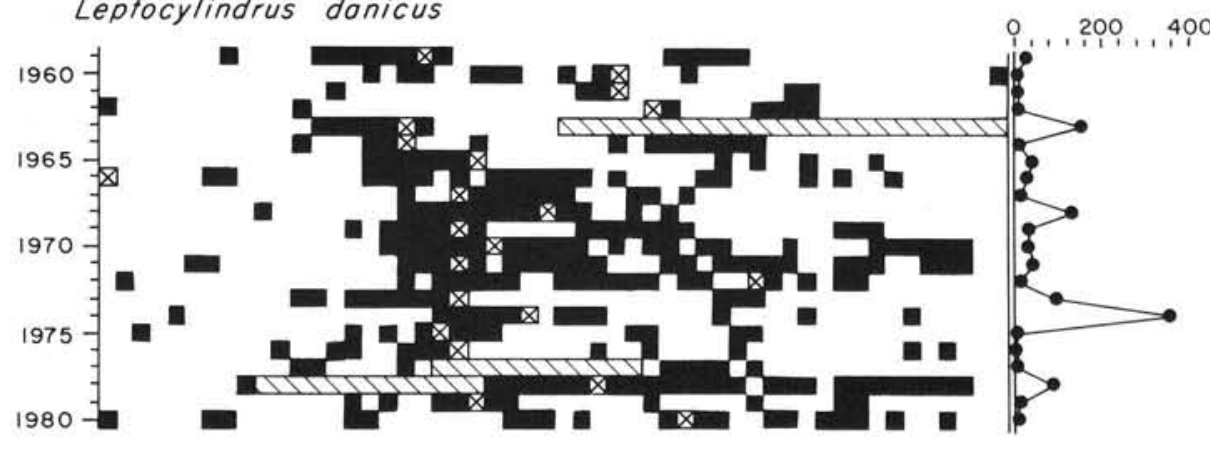

Thalassionema nitzschioides

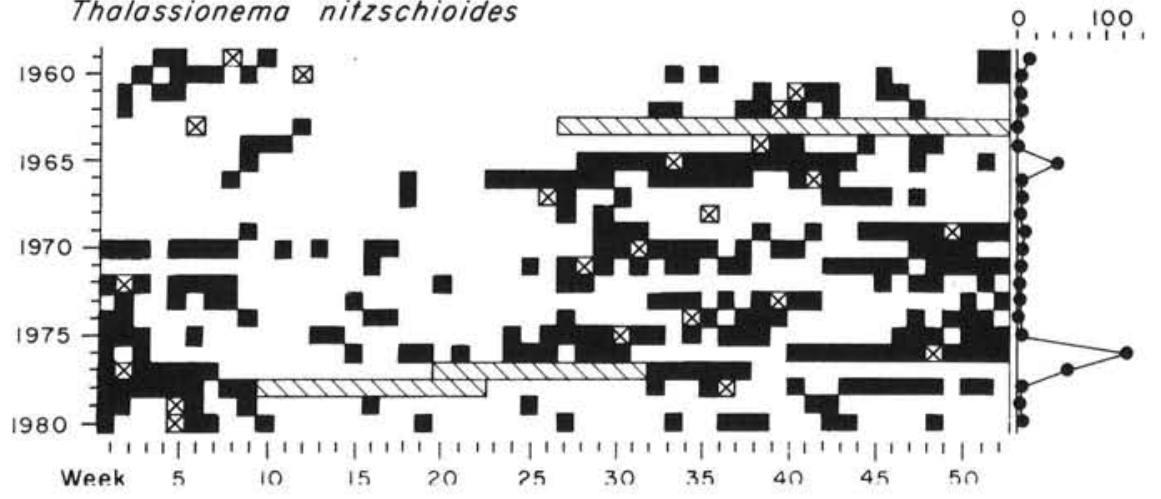

frequency of occurrence and lower population densities during the $1970 \mathrm{~s}$. $R$. fragilissima, more seasonal in occurrence and with recurrent annual maxima during the summer (usually Jul), was not common in the 1960s. It attained its greater annual maximum in 1969 , then became more prevalent during the following $10 \mathrm{yr}$. Although $R$. fragilissima was observed in
$20 \%$ of the samples collected, nearly half of its total abundance during the 22-yr sampling period can be attributed to a population density $\left(12,314\right.$ cells $\left.\mathrm{ml}^{-1}\right)$ recorded on $1 \mathrm{~d}$ (Table 1$)$. $R$. setigera had a persistent seasonal frequency of occurrence; predominantly a winter species, it occasionally reached its annual maximum during the summer. Similar to the other 


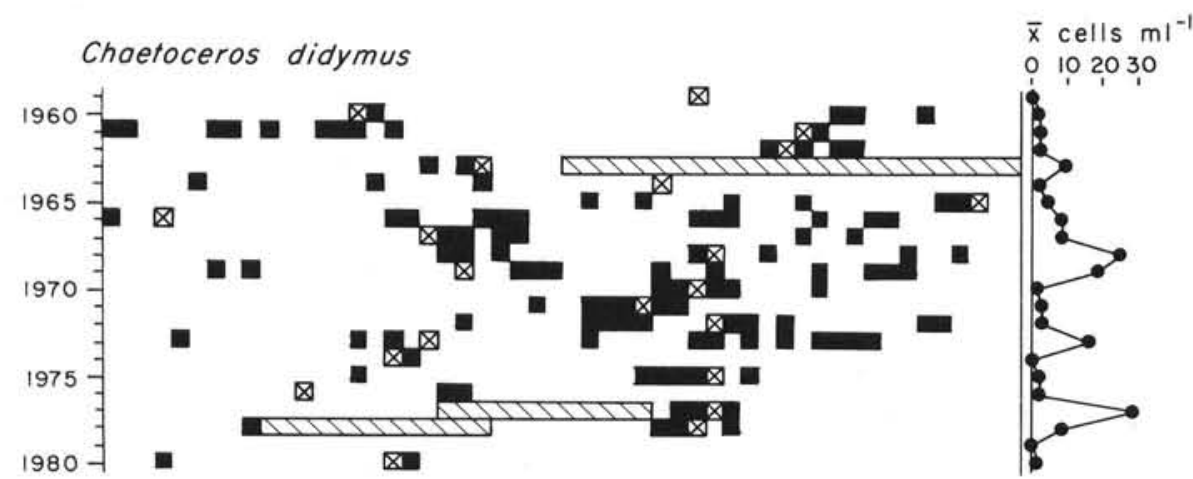

Chaetoceros curvisetum

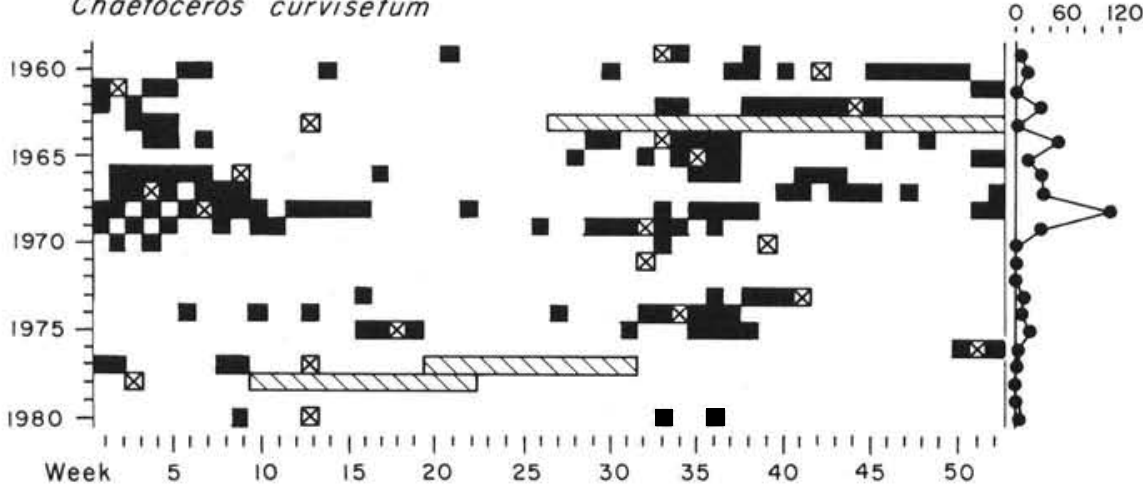

Fig. 5. Occurrence of Chaetoceros curvisetum and $C$. didymus in Narragansett Bay, 1959-1980. Otherwise, as for legend to Fig. 1

Rhizosolenia species, $R$. setigera attained greater annual maxima in the late 1960s.

Massartia (Katodinium) rotundatum, one of the most dominant flagellates in Narragansett Bay (Fig. 2), attained annual maxima in all seasons during the 22-yr sampling period. Commonly encountered from 1959 to 1962 , it occurred infrequently during the following $12 \mathrm{yr}$ (1963 to 1974), and in some years was not recorded. Its frequency of occurrence increased in 1975 , and the largest populations observed to date were recorded from 1978 to 1980 .

Prorocentrum redfieldii $(=P$. triestinum) and $P$. triangulatum, among the most dominant flagellates in Narragansett Bay (Fig. 2), exhibited nearly identical patterns of occurrence. Their yearly maxima usually occurred during early summer, their occurrence closely associated with that of Olisthodiscus luteus. P. redfieldii was the more abundant of the 2 Prorocentrum species, although they occurred with the same frequency in the plankton samples. $P$. redfieldii exhibited maximal abundance in 1962 and 1965-1966, while $P$. triangulatum attained highest cell densities in the late $1970 \mathrm{~s}$.

Thalassionema nitzschioides, while predominantly a member of summer and fall plankton assemblages, frequently occurred in the winter flora (Fig. 4). It exhibited maximum yearly abundances in summer, fall and winter; highest population densities were recorded during 1976 and 1977.

\section{Light and temperature}

Mean weekly levels of incident light intensity and surface water temperature for the 22 -yr period are plotted in Fig. 7. Weekly mean light intensity ranged from 634 to $67 \mathrm{ly} \mathrm{d}^{-1}$ and temperature from 24.5 to $-1.7^{\circ} \mathrm{C}$. The greatest interannual variations in light intensities occurred from May to Aug; temperature variations were less pronounced on a seasonal basis.

\section{Principal components' analysis}

Thirty principal components, which corresponded to the number of species used, were generated. Nine of these vectors, which accounted for $54 \%$ of the variation within the data, were initially retained for evaluation. They were selected because their eigenvalues were greater than 1.0 and the highest factor loadings for each species were within these 9 vectors (Jeffers, 1967). The factor loading matrix of the PCA indicates the correlation between each principal component and each species (Table 2).

Of the 30 species used, 17 had their strongest correlation within the first 2 principal components (PC1, PC2). These 2 components reflect $21 \%$ of the variation within the species data. The variability in individual species occurrences summarized by these 2 vectors becomes evident when PC1 is plotted against PC2 
Fig. 6. Occurrence of Rhizosolenia delicatula, $R$. fragilissima and $R$. setigera in Narragansett Bay, 1959-1980. Otherwise, as for legend to Fig. 1

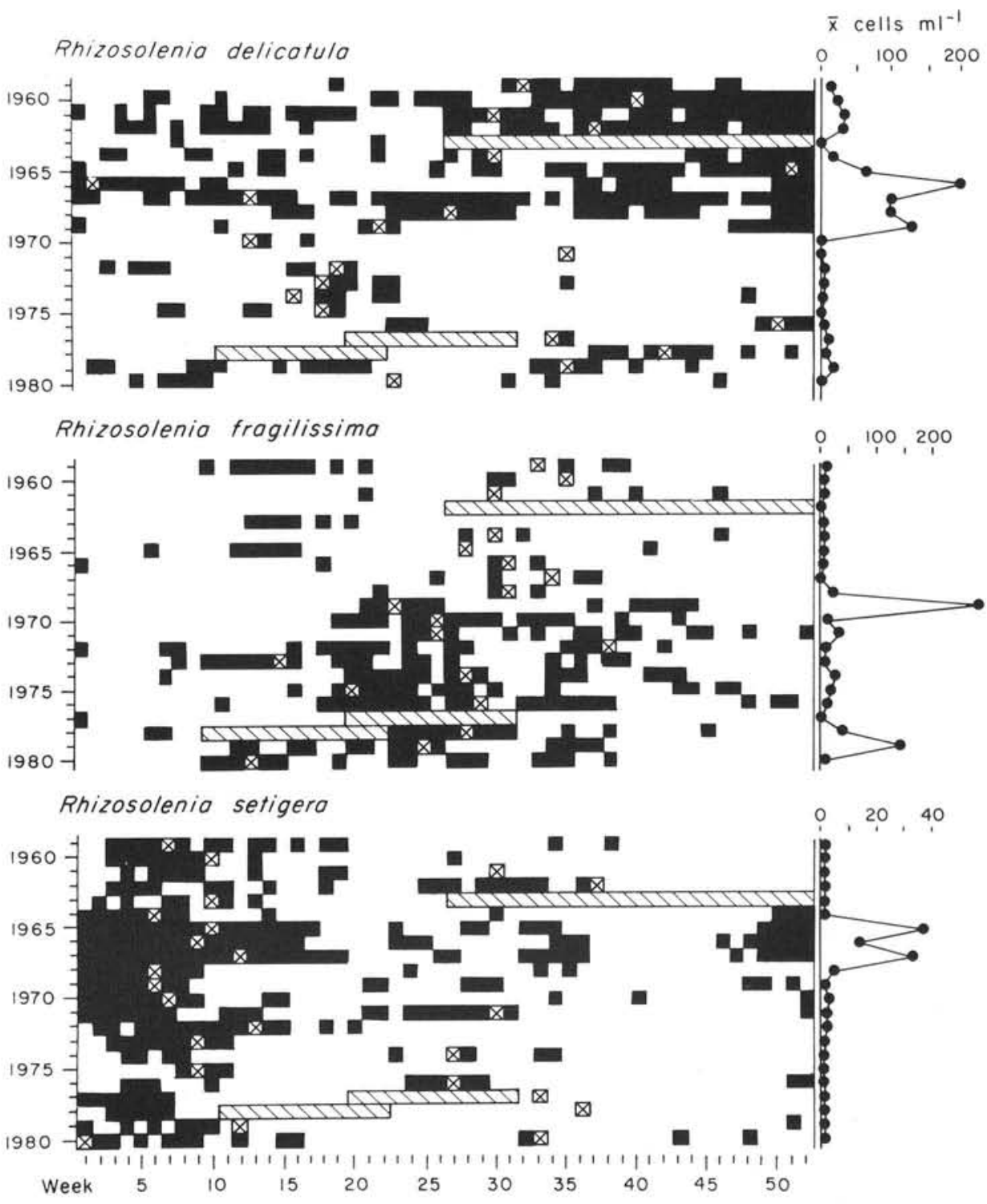

(Fig. 8). The distances between the plotted species points provide a relative measure of the degree of similarity between species with respect to both their seasonal occurrence and magnitude of abundance. The plot of the first 2 principal components also sorts the species relative to their temporal patterns of occurrence. PC1 establishes a temperature gradient, aligning individual species along a summer-winter axis. Thalassiosira nordenskioeldii and Detonula confervacea, which have high negative correlations with PC1, are characteristic members of winter phytoplankton assemblages in Narragansett Bay. They occur during Jan, Feb and Mar. In contrast, the motile species Prorocentrum redfieldii, $P$, triangulatum, Olisthodiscus Iuteus, Pyramimonas torta and Gymnodinium sp. had strong positive correlations with PC1. Members of this group are typically summer species. The seasonal occurrence and abundance patterns of the remaining taxa align on the seasonal gradient established by these obvious summer and winter groups. Species in the first quadrant generally attained their highest cell densities during summer, although their annual maxima may occur from late spring through fall. These species include Leptocylindrus danicus, Rhizosolenia fragilissima and Thalassionema nitzschioides. Species most often members of winter phytoplankton assemblages (they may persist in smaller numbers at other times of year) have stronger negative loadings with PC1. These include Rhizosolenia setigera and Chaetoceros debilis.

The relative degree of variation in temporal occurrence, which reflects the length of time a species is present during an annual cycle, seems to be expressed in PC2. Species having low correlation with this vector generally exhibited a specific seasonal occurrence, such as the summer and winter taxa mentioned above. 
Table 2. Factor loading matrix, eigenvalues $(\lambda)$ and cumulative proportion of total variance explained by each vector of the principal components' analysis. Values less than 0.25 or greater than -0.25 are not indicated. For each species, the loading with the highest absolute value is underlined. Acronyms (acr) for Fig. 8 are indicated

\begin{tabular}{|c|c|c|c|c|c|c|c|c|c|c|}
\hline Species & acr & 1 & 2 & 3 & 4 & 5 & 6 & 7 & 8 & 9 \\
\hline P. triangulatum & pt & .59 & & & & & .40 & & & \\
\hline Gymnodinium sp. & gs & .56 & & & .38 & & & & & \\
\hline O. luteus & ol & .53 & & & .37 & & & & & .27 \\
\hline P. redfieldii & $\mathrm{pr}$ & .51 & & & .36 & & .28 & & & \\
\hline P. torta & py & .45 & & & .37 & & -.23 & & & \\
\hline C. amphioxeia & ca & .28 & & .67 & & & -.30 & & & \\
\hline Thalassiosira sp. & ts & .35 & .33 & .54 & & & & & & \\
\hline L. danicus & ld & .29 & .30 & & -.27 & .41 & & -.24 & & \\
\hline N. closterium & $\mathrm{nc}$ & .46 & .47 & & & & & & & \\
\hline C. pelagica & $\mathrm{cp}$ & .37 & .45 & & & & & & & -.25 \\
\hline R. fragilissima & rf & .26 & .37 & & & .27 & .25 & & & \\
\hline T. rotula & $\operatorname{tr}$ & & .59 & & & & & & & \\
\hline T. nitzschioides & $\mathrm{tz}$ & & .45 & & & -.34 & & .30 & & \\
\hline C. didymus & $\mathrm{cd}$ & & .42 & -.27 & & & & & .42 & \\
\hline C. curvisetum & $\mathrm{cm}$ & -.27 & 39 & -.26 & & -.34 & & & & \\
\hline A. glacialis & ag & -.34 & .46 & -.26 & & & & & & \\
\hline S. costatum & sc & -.43 & .53 & & & & & & & \\
\hline K. rotundatum & $\mathrm{mr}$ & & & .57 & .28 & & -.29 & & & \\
\hline C. diadema & ci & & &.$\overline{28}$ & & & .34 & .32 & & .33 \\
\hline C. affinis & cf & & & & & & & & .50 & .33 \\
\hline L. minimus & $\operatorname{lm}$ & & & & -.37 & .35 & & & & .35 \\
\hline C. tortissima & ct & & & & & .36 & & & & 42 \\
\hline C. gracilis & $\mathrm{cg}$ & & & & & .33 & -.34 & .63 & & \\
\hline S. trochoidea & st & & & -.26 & .30 & .29 & & .37 & & \\
\hline R. delicatula & rd & & & -.37 & & & & & -.47 & .34 \\
\hline C. debilis & $\mathrm{cb}$ & & & & & & & -.34 & & \\
\hline C. compressus & cc & -.31 & & & & .41 & & & .31 & \\
\hline C. similis & cs & -.43 & & & .35 & & & & -.29 & \\
\hline D. confervacea & dc & -.68 & & .29 & .26 & & .30 & & & \\
\hline$T$. nordenskioeldii & tn & -.72 & & & & & & & & \\
\hline$\lambda$ & & 3.91 & 2.48 & 1.98 & 1.57 & 1.44 & 1.33 & 1.23 & 1.11 & 1.07 \\
\hline cum. $\%$ var. & & 13 & 21 & 28 & 33 & 38 & 42 & 46 & 50 & 54 \\
\hline
\end{tabular}

Higher positive loadings in the second vector of the factor loading matrix are associated with species which occur for longer periods of time. Thalassiosira rotula, Asterionella glacialis, Nitzschia closterium and, especially, Skeletonema costatum occurred and exhibited annual maxima throughout the year.

Interpretation of the remaining vectors of the PCA is obscure. They cannot be correlated to specific characteristics of temporal variation, but serve to define further those aspects of seasonality and temporal occurrence established by PC1 and PC2 and described above.

Regression of light data on the principal components showed very low $(<1.03 \mid)$ or no correlation with any of the principal component vectors. Regression analysis revealed temperature to be strongly $(\mathrm{r}=-0.66)$ correlated with PC1.

\section{DISCUSSION AND CONCLUSIONS}

Principal components' analysis increasingly has been used to group the species comprising phyto- plankton communities into assemblages characterized by common spatial and/or temporal occurrences under given environmental conditions, watermass type or seasonally changing habitats (Margalef and Bernaldez, 1969; Blasco, 1971; Garrison, 1979; Colebrook, 1982). Levandowsky (1972) has successfully applied a somewhat different, though mathematically equivalent, approach. The practical impetus for such statistical processing is to reduce an often unwieldy data base into more manageable summary statements of apparent environmental preferences of the individual species and assemblages represented in the community. Differences in statistical techniques, data set quality and problem formulation preclude specific comparisons between previous studies, ours included. Collectively, however, these studies reveal that natural communities are composed of statistically recognizable assemblages representing taxonomic structural sub-units. Several clusters of species (= assemblages) may co-occur within the same community, and they appear to be characterized by properties similar to those of species succession (Smayda, 1980). Presum- 

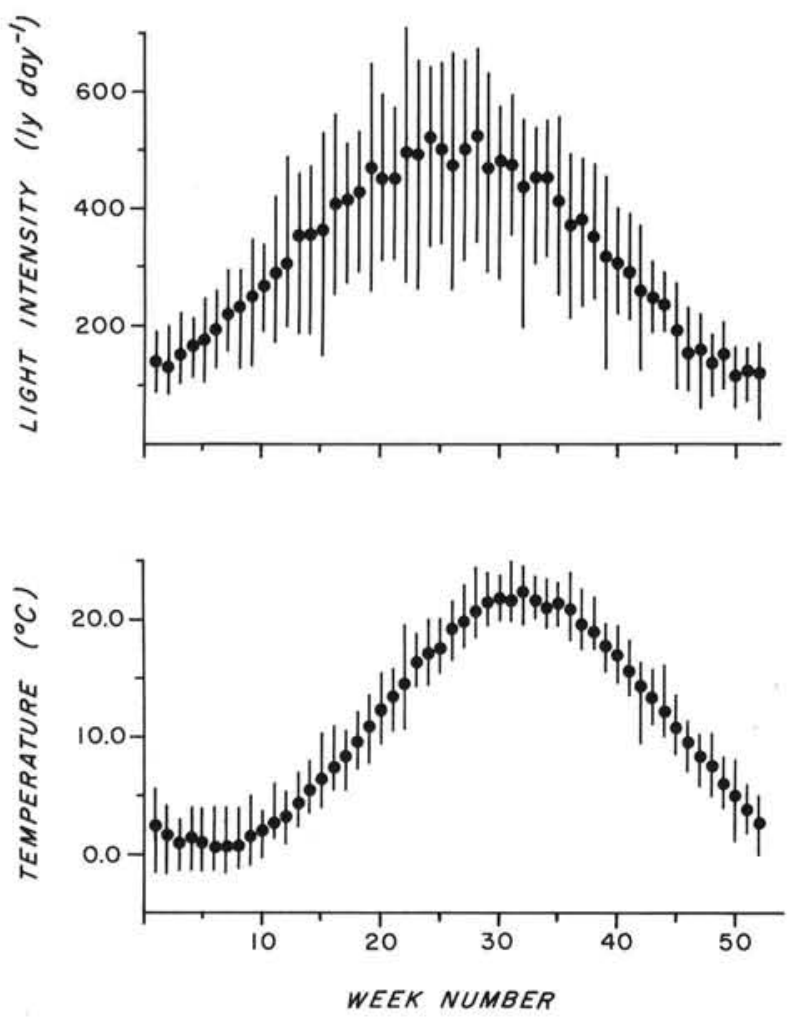

Fig. 7. Mean weekly levels and ranges in surface temperature and mean incident light intensities for Narragansett Bay, 1959-1980

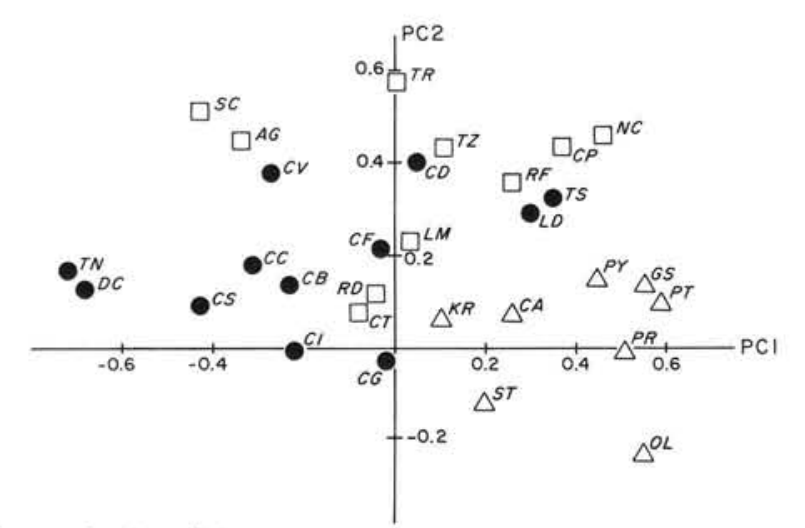

spore-forming diatom

$\square$ non-spore-forming diatom

$\triangle$ flagellate

Fig. 8. Plot of principal components PC1 vs PC2 based on principal components analysis of 30 major species in Narragansett Bay (species acronyms explained in Table 2)

ably, the organization and spatial and temporal changes of these assemblages occur in response to environmental conditions.

The PCA results for the 30 major phytoplankton species in Narragansett Bay summarized their individual seasonal occurrence patterns over the 22-yr study period. Winter species (e.g. Thalassiosira nordenskioeldii, Detonula confervacea) have high negative loadings (correlations) with PC1; summer species (e.g. Olisthodiscus luteus, Prorocentrum triangulatum) have high positive loadings; spring (e.g. Leptocylindrus danicus) and fall (e.g. Thalassiosira rotula) species have intermediate values. Positioning of species along PC2, going from low to high factor loadings, corresponds to a gradient of very transient to persistent occurrence in the seasonal plankton communities. Our identification of PC1 as a seasonal temperature gradient is supported by regression analysis of temperature on the principal components. Temperature had a very strong correlation with PC1, emphasizing the temporal character of this vector, whereas its correlation with light intensity was much weaker. Although both temperature and light are seasonally variable, this low correlation between PC1 and light may be due to the higher degree of interannual variability in weekly light values compared to the relative stability of temperature (Fig. 7). Thus, the PCA and associated regression analysis of light and temperature suggest that the seasonal and interannual occurrence patterns of the major phytoplankton species in Narragansett Bay, and variations in these, are related more to temperature than to light.

The low cumulative percent $(22 \%)$ of the total variance accounted for by PC1 and PC2 does not compromise our ensuing focus on the apparent regulation by temperature of the seasonal occurrence patterns in the major phytoplankton species of Narragansett Bay. Gauch (1982) has shown that ordination selectively recovers patterns affecting several species simultaneously in early ordinate axes, while 'selectively' deferring noise affects to later axes. Thus, ordinations of field data frequently provide useful insights even when the percentage of variance accounted for by the first few ordination axes is low.

A clustering of the 30 species into 3 biological groups is suggested by their general ordination patterns along the apparent seasonal temperature gradient (Fig. 8): motile species; diatoms which produce resting spores; and eurythermic diatom species which do not produce resting spores. The motile species, primarily dinoflagellates, exhibit a restricted seasonal occurrence at higher temperature. Among those species which produce a resting spore, both warm and cold-water taxa are represented, and taxa which are highly transient (e.g. Chaetoceros didymus) or moderately persistent (Thalassiosira nordenskioeldii and Detonula confervacea). Among the eurythermic species which do not form resting spores, there are representatives which favor higher (Phaeodactylum tricornutum), intermediate (Thalassiosira rotula), and lower levels of temperature (Skeletonema costatum). 
This latter species' cluster also includes the three pelagic, pennate species represented amongst the dominant species: Asterionella glacialis, PhaeodactyIum tricornutum and Thalassionema nitzschioides.

The apparent seasonal ordination of the dominant species in Narragansett Bay in response to temperature generally agrees with their expected seasonal occurrence based on available autecological data. The growth-temperature relationships for such species in laboratory culture are presented in Fig. 9 and Table 3. The dominant winter species, Detonula confervacea and Thalassiosira nordenskioeldii, are characterized by the lowest optimal growth temperatures and narrowest temperature ranges. The growth-temperature characteristics of species dominant during spring and early summer (Leptocylindrus danicus, Rhizosolenia fragilissima, Chaetoceros didymus, Olisthodiscus luteus) are intermediate (Fig. 9B, C, E) between those for cold-water diatoms and eurythermal species such as Asterionella glacialis, Skeletonema costatum, Thalassiosira rotula and Phaeodactylum tricornutum (Fig. 9D, F). There is a possibility that Nitzschia closterium recorded for Narragansett Bay is identical to Phaeodactylum tricornutum. Since their temperaturegrowth and temperature-occurrence relationships appear to be similar, the more detailed experimental data available for Phaeodactylum are used in Figs. 9F, 11.) Thalassionema nitzschioides stands out from the other eurythermal species in its relatively better growth at the lowest temperatures.

Table 3. Temperature means and ranges $\left({ }^{\circ} \mathrm{C}\right)$ during population maxima and entry and exit occurrences of some dominant species in Narragansett Bay compared to their temperature optima and range for growth in culture ( - seasonal cycle pattern prevents meaningful estimate)

\begin{tabular}{|c|c|c|c|c|c|c|c|c|}
\hline \multirow[b]{2}{*}{$\begin{array}{l}\text { Maximun } \\
\overline{\mathrm{X}} \pm \text { S.D. }\end{array}$} & \multirow[b]{2}{*}{ Range } & \multicolumn{4}{|c|}{ Narragansett Bay } & \multicolumn{3}{|c|}{ Laboratory } \\
\hline & & $\begin{array}{c}\text { Entry } \\
\overline{\mathrm{X}} \pm \mathrm{S} . \mathrm{D} .\end{array}$ & Range & $\begin{array}{c}\text { Exit } \\
\overline{\mathrm{X}} \pm \text { S.D. }\end{array}$ & Range & Optimum & Range & Source \\
\hline \multicolumn{9}{|c|}{ Detonula confervacea } \\
\hline $1.8 \pm 1.7$ & $-0.5-6.4$ & $2.5 \pm 1.9$ & $-1.1-5.4$ & $6.7 \pm 2.9$ & $1.0-11.9$ & 12 & $<2-16$ & Smayda (1969) \\
\hline \multicolumn{9}{|c|}{ Chaetoceros diadema } \\
\hline $2.7 \pm 3.6$ & $-0.9-10.2$ & $1.7 \pm 1.9$ & $-0.6-5.7$ & $4.4 \pm 4.1$ & $-0.9-10.5$ & $\geq 6$ & $-1.5->17$ & Baars $(1979,1981)$ \\
\hline \multicolumn{9}{|c|}{ Thalassiosira nordenskioeldii } \\
\hline $2.8 \pm 1.8$ & $-0.6-5.6$ & $3.2 \pm 3.2$ & $0.5-11.3$ & $10.0 \pm 3.1$ & $3.1-15.0$ & 10 & $<0-15^{+}$ & Durbin $(1974)^{\circ}$ \\
\hline \multicolumn{9}{|c|}{ Chaetoceros debilis } \\
\hline $7.4 \pm 5.7$ & $0.5-18.9$ & - & - & - & - & $\geq 12$ & $0-21$ & Baars (1979) \\
\hline \multicolumn{9}{|c|}{ Rhizosolenia setigera } \\
\hline $7.5 \pm 9.0$ & $0.3-23.0$ & $3.2 \pm 3.2$ & $-1.5-9.8$ & $17.3 \pm 6.9$ & $3.0-23.2$ & 14 & $1-23$ & Hulburt (1982) \\
\hline Asterionella japonica & $\begin{array}{l}\text { japonica } \\
-0.8-23.0\end{array}$ & - & - & - & - & 25 & $<0-30$ & Teng (unpubl.) \\
\hline \multicolumn{9}{|c|}{ Chaetogeros didymus } \\
\hline \multicolumn{9}{|c|}{ Skeletonema costatum } \\
\hline $13.4 \pm 9.3$ & $0.2-23.0$ & - & - & - & - & $22-25$ & $<0-\sim 31$ & $\begin{array}{l}\text { Yoder }(1979) ; \\
\text { Hulburt }(1982) \cdots\end{array}$ \\
\hline \multicolumn{6}{|c|}{ Thalassionema nitzschioides } & 20 & $<1-27$ & Hulburt $(1982)^{\cdots}$ \\
\hline \multicolumn{9}{|c|}{ Thalassiosira rotula } \\
\hline $15.8 \pm 6.5$ & $0.8-23.0$ & - & - & - & - & 25 & $<0-30$ & Krawiec (1982) \\
\hline \multicolumn{9}{|c|}{ Leptocylindrus danicus } \\
\hline $15.9 \pm 5.1$ & $3.2-22.5$ & - & - & - & - & $15 \cdots$ & $\sim 2-25$ & Verity (1982) \\
\hline \multicolumn{9}{|c|}{ Olisthodiscus luteus } \\
\hline $17.2 \pm 3.6$ & $9.4-21.7$ & $14.2 \pm 3.7$ & $7.2-21.5$ & $12.6 \pm 6.4$ & $2.9-23.8$ & 20 & $<5->30$ & Tomas (1978a) \\
\hline \multicolumn{9}{|c|}{ Rhizosolenia fragilissima } \\
\hline $18.6 \pm 5.0$ & $5.6-23.0$ & - & - & - & - & 18 & $7->30$ & $\begin{array}{l}\text { Ignatiades and } \\
\text { Smayda }(1970)\end{array}$ \\
\hline \multicolumn{9}{|c|}{ Cerataulina pelagica } \\
\hline $19.1 \pm 3.6$ & $11.0-23.0$ & $13.4 \pm 6.9$ & $4.0-22.0$ & $15.5 \pm 6.5$ & $4.2-22.0$ & ? & $<13>$ & Baars (1981) \\
\hline \multicolumn{9}{|c|}{ Scrippsiella trochoidea } \\
\hline \multicolumn{9}{|c|}{ Phaeodactylum tricornutum } \\
\hline
\end{tabular}


Fig. 9. Laboratory growth rates of dominant species in Narragansett Bay expressed as a percentage of maximal daily growth rate; divisions $\mathrm{d}^{-1}$ indicated below in brackets. Laboratory clones isolated from Narragansett Bay unless specified otherwise. (A) Thalassiosira nordenskioeldii (1.80): Durbin, (1974); Detonula confervacea (1.48): Smayda (1969); Thalassionema nitzschioides (1.84), Cape Cod clone: Hulburt (1982). (B) Rhizosolenia setigera (0.83), Cape Cod clone: Hulburt (1982); Leptocylindrus danicus (2.70): Verity (1982). (C) Rhizosolenia fragilissima (1.17): Ignatiades and Smayda (1970); Chaetoceros didymus (1.8), Atlantic slope water clone: Hulburt (1982). (D) Asterionella glacialis (2.87): Teng (unpubl.); Skeletonema costatum (•) (3.7): Yoder (1979); $\Delta$ (2.21), Long island Sound clone: Hulburt (1982). (E) Olisthodiscus luteus (1.75): Tomas (1978a); Scrippsiella trochoidea (?): from Braarud (1961). (F) Thalassiosira rotula (1.8): Krawiec (1982); Phaeodactylum tricornutum (1.07): $\mathrm{Li}$ (1980)

This analysis produced an unexpected finding - the apparent predominance of eurythermal species (Fig. 9) among the 30 major species. The extreme temperature range in Narragansett Bay is approximately -1.8 to $27^{\circ} \mathrm{C}$, with the average annual temperatures during 1959-1980 ranging from 9.9 to $11.6^{\circ} \mathrm{C}$ (Smayda, unpubl.). Moreover, average monthly mean temperature is below $\sim 10^{\circ} \mathrm{C}$ for $6 \mathrm{mo}$ (November-April). Although the poor representation of boreal species among the dominant species in Narragansett Bay remains puzzling, the generally eurythermic nature of the latter is consistent with Hulburt's (1982) conclusion that 2 categories of phytoplankton occur in the sea with regard to temperature adaptation. The temperate class (= clones) of species grow at temperatures ranging from about 2 to $25^{\circ} \mathrm{C}$, while the tropical class has a growth range from about 12 to $34^{\circ} \mathrm{C}$.

The general ordination of the seasonal occurrences of the dominant species in Narragansett Bay along a

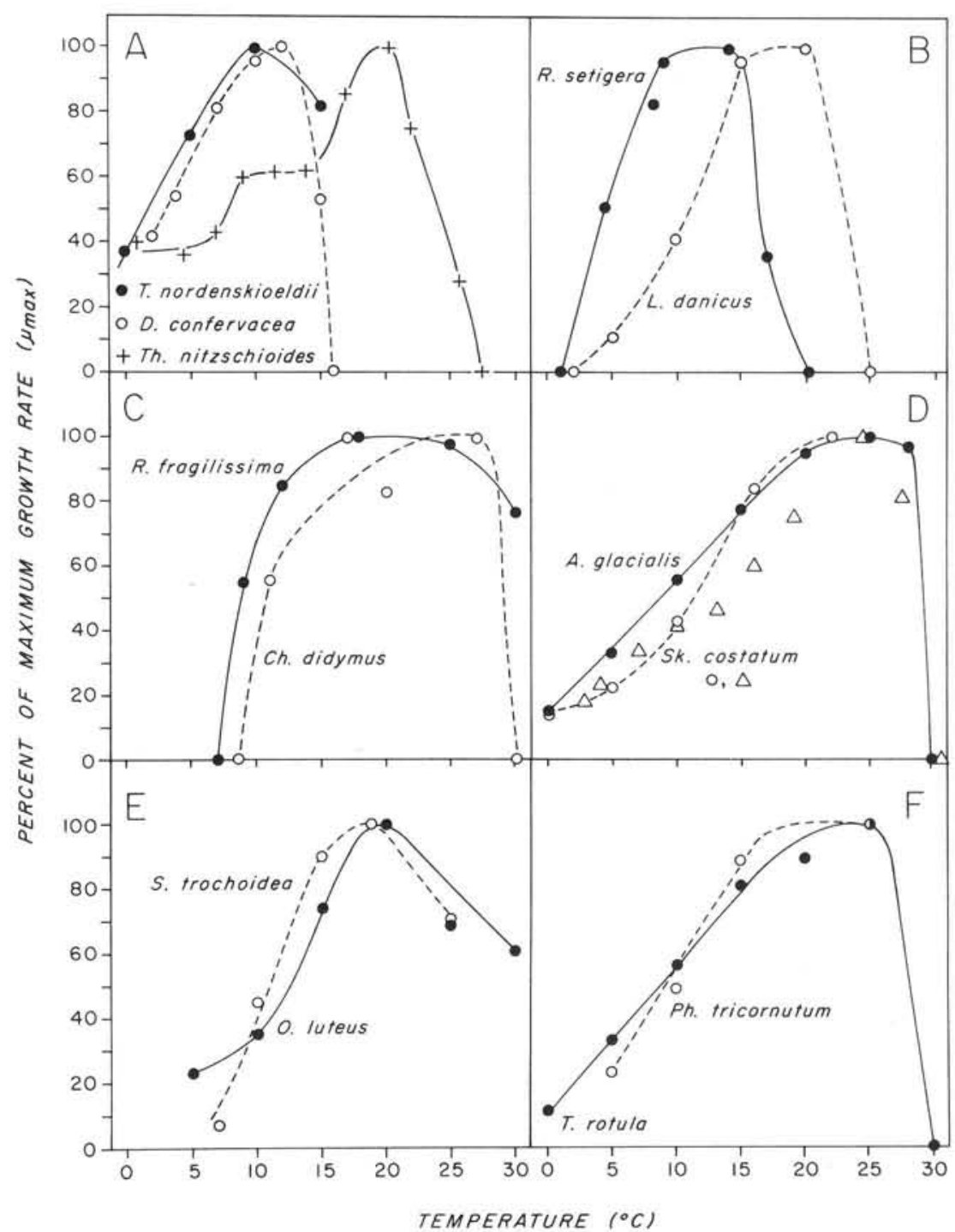

temperature gradient also agrees with Pratt's (1959) earlier (1952-1956) observations on their seasonal occurrence in this Bay. The seasonal progression in community dominance by Thalassiosira nordenskioeldii and Chaetoceros diadema $\left(3^{\circ} \mathrm{C}\right)$ to $C$. debilis $\left(6^{\circ} \mathrm{C}\right)$ to C. compressus $\left(9^{\circ} \mathrm{C}\right)$ to Skeletonema costatum $\left(12^{\circ} \mathrm{C}\right)$ in the Gulf of Maine (Gran and Braarud, 1935) is analogous to their seasonal progression in Narragansett Bay (Fig. 8). It might be concluded therefore that temperature is a primary determinant in the succession of dominant species in Narragansett Bay. Several lines of evidence weaken this view, however.

The frequency with which the different species attained their annual maximum at $2{ }^{\circ} \mathrm{C}$ intervals during the 1959-1980 observational period is shown in Fig. 10. The temperature range over which they attained annual maxima during this $22-\mathrm{yr}$ period is indicated in Fig. 11 and Table 3. The optimal temperatures for growth under laboratory conditions are also 

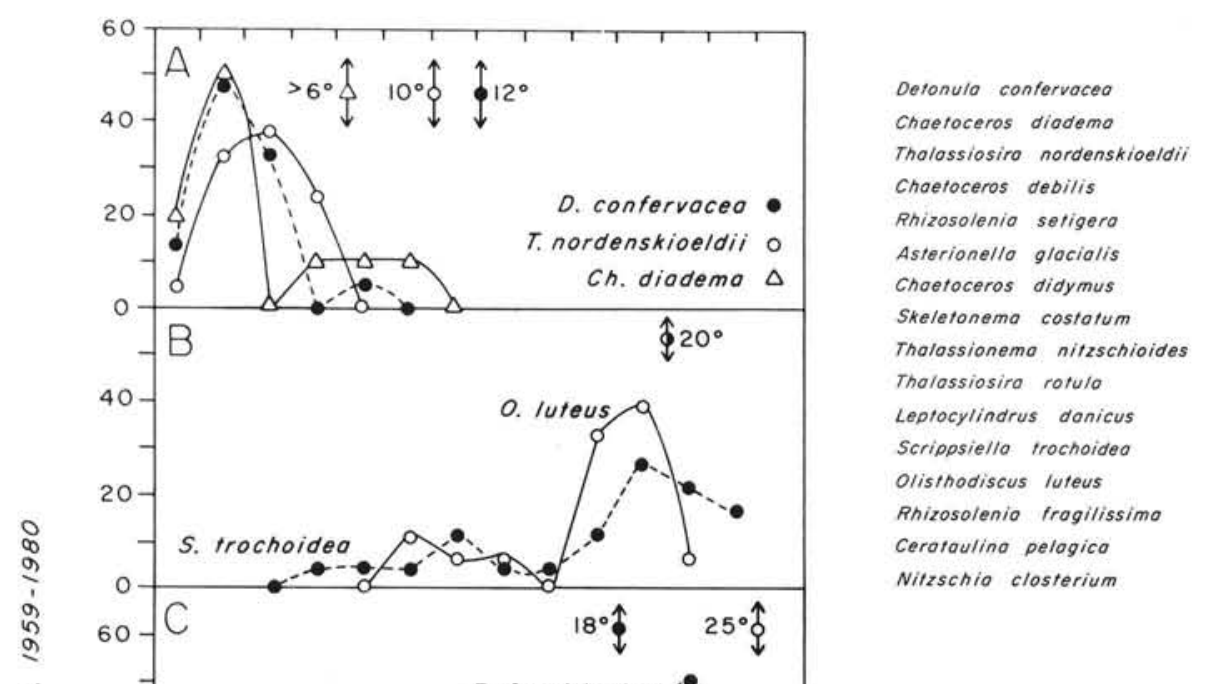

$\begin{array}{lllllllllllllll}-2 & 0 & 2 & 4 & 6 & 8 & 10 & 12 & 14 & 16 & 18 & 20 & 22 & 24 & 26\end{array}$

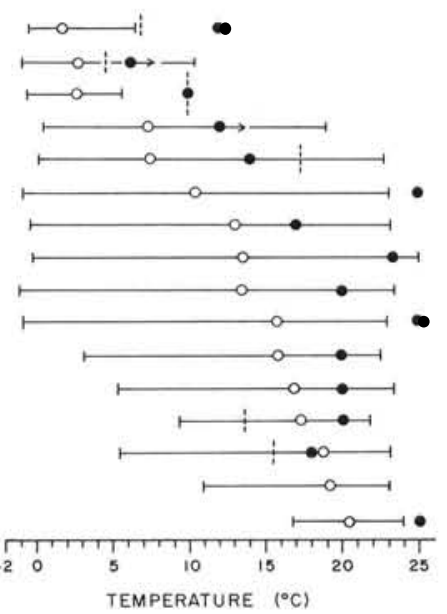

Fig. 11. Range $(\longmapsto-1)$ and mean temperature $(0)$ accompanying annual abundance maxima of major species in Narragansett Bay, and their mean exit temperatures (dashed line), where they can be determined, during 1959-1980 compared to their (excluding C. pelagica) optimal growth temperature in laboratory culture $(\bullet) . \bullet$ symbols for $C$. diadema and $C$. debilis explained in legend to Fig. 10

indicated. Temperature at the time of their annual field maxima varied significantly for all species. The range was $7^{\circ} \mathrm{C}$ for Detonula confervacea $\left(-0.5\right.$ to $\left.6.4^{\circ} \mathrm{C}\right)$, Thalassiosira nordenskioeldii and Nitzschia closterium; $12^{\circ} \mathrm{C}$ for Cerataulina pelagica $\left(11\right.$ to $23^{\circ} \mathrm{C}$ ) and Olisthodiscus luteus; 18 to $19^{\circ} \mathrm{C}$ for Leptocylindrus danicus $\left(3.2\right.$ to $\left.22.5^{\circ} \mathrm{C}\right)$, Rhizosolenia fragilissima, Chaetoceros debilis and Scrippsiella trochoidea, and $>23^{\circ} \mathrm{C}$ for the remaining species. Mean temperature of the in situ maxima and optimal temperature for laboratory growth were equal only for Rhizosolenia fragilissima. Otherwise, the mean temperatures for the annual field maxima were 3 to $14^{\circ} \mathrm{C}$ lower $(\Delta)$ than the laboratory optima (Table 3). Both stenothermal (e.g. Detonula confervacea, $\Delta 10^{\circ} \mathrm{C}$ ) and eurythermal species (Asterionella glacialis, $\Delta 14^{\circ} \mathrm{C}$; Skeletonema costatum, $\Delta 9$ to $12^{\circ} \mathrm{C}$ ) exhibited significant anomalies. Most species experienced in situ their apparent optimal growth temperature established in culture studies. However, Detonula confervacea, Thalassiosira nordenskioeldii, Asterionella glacialis and Thalassiosira rotula, usually disappeared from the plankton communities at temperatures below their laboratory growth optimum.

The frequency distribution of in situ maxima at various temperatures for the different eurythermal species also challenges the notion that temperature regulates the seasonal succession patterns of the 30 major species in Narragansett Bay. Skeletonema costatum and Rhizosolenia setigera exhibited cold-water and warm-water peaks, but not at intermediate tempera-
Fig. 10. Frequency (\%) with which the annual maximal abundances of the major species occurred during 1959-1980 at different temperature intervals. Arrows: laboratory growth temperature optima. $>6^{\circ}$ and $>12^{\circ} \mathrm{C}$ for $C$. diadema and $C$. debilis indicate that autecological experimental data are incomplete and that laboratory optimal temperature is probably higher for each species 
tures (Fig. 10D). Asterionella glacialis and Thalassionema nitzschioides, in contrast, exhibited occasional peaks at intermediate temperatures in addition to cold- and warm-water maxima (Fig. 10E). Factors other than temperature appear to regulate the timing of the annual maxima of these eurythermic species.

Significant interannual variability in temperature accompanies the annual maxima of the major species. There are also substantial anomalies between observed and expected field behavior, were in situ responses regulated by temperature alone. These suggest that the effect of temperature on phytoplankton species succession in Narragansett Bay is more indirect than implied by the results of the principal components' analysis. For those species which disappear from the community at temperatures below their growth optimum, this is self-evident. The considerable interannual variation in apparent temperature optimum accompanying maximal field abundance also suggests that other controlling factors, which probably change interannually (Smayda, 1973), regulate this succession. This does not preclude an influence of factor interactions with temperature; nutrients, for example (see Fig. 14.16 in Smayda, 1980). Nor can we exclude the possibility (Braarud, 1961) that species which require a fairly high level of nutrients might show a seasonal occurrence pattern similar to cold-water species, or that species tolerant of low nutrient levels might show warm-water occurrence patterns. Braarud (1962) also pointed out that the discrepancies between expected (from temperature) and observed distributions of Skeletonema costatum and Thalassiosira nordenskioeldii, two of the major species in Narragansett Bay, indicate caution is necessary in assessing temperaturemediated in situ behavior. Eppley (1972) and Goldman and Ryther (1976) have concluded that temperature seems to have little effect on the production of phytoplankton in the sea. Although our observations are peripheral to this as yet unresolved aspect of the temperature-phytoplankton interaction, they are pertinent to the Goldman and Ryther view (p. 1137-8) that the seasonal appearance of many species in natural marine waters' ... ' 'is a prime example of how temperature' ... 'does indeed exert a tremendous influence on species competition'. If these authors also intended to apply the outcome of such competition to species succession, then this conclusion would not appear to apply to Narragansett Bay.

The annual entry temperature, i.e. first detectable occurrence, of the dominant species in Narragansett Bay varied considerably between years (Fig. 10 and 11; Table 3). Two of the 3 PCA cluster groups evident statistically were comprised of diatom species. One group comprised species capable of forming resting spores, and the other grouped non-spore forming
Table 4. Correspondence between spore-producing capability of dominant species in Narragansett Bay and apparent temperature-growth behavior in laboratory culture

\begin{tabular}{|c|c|c|c|}
\hline \multirow[t]{2}{*}{ Species } & \multicolumn{3}{|c|}{ Growth temperature $\left({ }^{\circ} \mathrm{C}\right)$} \\
\hline & Spore & $\begin{array}{l}\text { Opti- } \\
\text { mum }\end{array}$ & Range \\
\hline Chaetoceros debilis & + & $\geq 12$ & $0-21$ \\
\hline Chaetoceros diadema & + & $>6$ & $-1.5-17$ \\
\hline Chaetoceros didymus & + & 17 & $8.5-30$ \\
\hline Detonula confervacea & + & 12 & $<2-16$ \\
\hline Leptocylindrus danicus & + & $15^{*}$ & $2-25$ \\
\hline Olisthodiscus luteus & $+\cdots$ & 20 & $<5->30$ \\
\hline Rhizosolenia setigera & + & 14 & $1-23$ \\
\hline Scrippsiella trochoidea & + & 20 & $<7->25$ \\
\hline Thalassiosira nordenskioeldii & + & 10 & $-1.5-23$ \\
\hline Asterionella glacialis & - & 25 & $<0-30$ \\
\hline Phaeodactylum tricornutum & - & 25 & $<5->25$ \\
\hline Rhizosolenia fragilissima & - & 18 & $7->30$ \\
\hline Skeletonema costatum & - & $22-25$ & $<0-31$ \\
\hline Thalassionema nitzschioides & - & 20 & $<1-27$ \\
\hline Thalassiosira rotula & - & 25 & $<0-30$ \\
\hline \multicolumn{4}{|c|}{$\begin{array}{l}\text { - Verity }(1982) \text { found equivalent growth at } 20^{\circ} \mathrm{C} \text {, but cells } \\
\text { deformedi }{ }^{\circ} \text { Has a bottom stage (Tomas } 1978 \mathrm{~b} \text { ) }\end{array}$} \\
\hline
\end{tabular}

eurythermic species (Fig. 8). Species which do not form spores generally tend to have a higher temperature optimum for growth than meroplanktonic species (Table 4). The entry temperature accompanying the first appearances of species from both groups varied considerably. Obviously, holoplanktonic species which are eurythermal must either maintain an indigenous population year-round, or depend on allochthonous seedings from contiguous waters. The data suggest that autochthonous stands of these species could seed their blooms in Narragansett Bay. Collectively, these species exhibit a very wide range in temperature tolerance (Table 4), which would allow them, possibly excluding Rhizosolenia fragilissima, to survive the frigid winter temperatures and elevated summer temperatures in Narragansett Bay. However, this does not resolve the question as to why their annual entry temperature should be so variable, particularly during those periods when interannual climatic variations in temperature do not explain the phenomenon. Allochthonous seedings, which vary in time, and therefore would be accompanied by variable incursion temperatures, may occur periodically.

The variable entry temperatures for vegetative cells of the resting-spore species would, at first hand, appear to be more readily explainable. Theoretically, one can invoke a mechanism wherein excystment into vegetative cells is both temperature-dependent and occurs over a range in temperature. The latter contrasts to a sudden release occurring at a given temperature. Through this excystment-germination strategy, resting-spore formers could undertake episodic germina- 
tions (= trial liberations), not all of which need be successful repopulations, until eventually a particular spawn(s) succeeds because of favorable environment and re-seeds the water column. Suitable temperature, light and water quality (EDTA-modifiable) conditions are required for successful germination of resting spores (Durbin, 1978; Anderson and Morel, 1979; Davis et al., 1980; Hollibaugh et al., 1981). Indeed, the occurrence of this theoretical germination sequence has been elegantly shown to occur over a range of increasing and decreasing temperatures for resting spores (hypnocysts) of the dinoflagellate Gonyaulax tamarensis (Anderson and Morel, 1979).

This recruitment mechanism cannot be applied generally to the meroplanktonic species in Narragansett Bay. Curiously, resting spores do not appear to survive more than a few weeks in the sediments of Narragansett Bay. Microscopic examination of sediment cores collected at monthly intervals failed to detect their presence (Hargraves and French, 1975), unlike for Monterey Bay, California (Garrison, 1981). Independent of this, the cryophilic spore-formers, Thalassiosira nordenskioeldii and Detonula confervacea, have special problems associated with summer dormancy in Narragansett Bay. Durbin (1978) demonstrated experimentally that the darkened spores of neither species can survive beyond $7 \mathrm{~d}$ at $20^{\circ} \mathrm{C}$. (Thalassiosira nordenskioeldii also does not form spores at $\geq 15^{\circ} \mathrm{C}$ ). Even higher temperatures characterize bottom waters each summer in Narragansett Bay for a 10-wk period (Smayda, unpubl.). This suggests that annual recruitment of these species into Narragansett Bay requires seeding from contiguous waters. This may partially explain the interannual variations in entry temperature. Braarud (1962), who evaluated the geographical distribution of Thalassiosira nordenskioeldii with respect to its temperature-growth response in culture, concluded (p. 637) it is an example of 'a doubtful case of temperature-controlled seasonal occurrence'.

Of the other major meroplanktonic species, Chaetoceros didymus and C. diadema have been shown to germinate between 7 and $21.4^{\circ} \mathrm{C}$, and $25^{\circ} \mathrm{C}$, respectively (Hollibaugh et al., 1981). Temperatures above $25.3^{\circ} \mathrm{C}$ were lethal to spores produced by both species, and germination was slow, if it occurred, below $8^{\circ} \mathrm{C}$. Both species would appear capable of surviving summer and winter sediment temperatures in Narragansett Bay. Leptocylindrus danicus spores can withstand temperatures between at least 2 and $10^{\circ} \mathrm{C}$, and would be expected to survive sediment temperatures during winter in Narragansett Bay. The apparent failure of these 3 species (and other meroplanktonic forms) to survive in the sediments of Narragansett Bay, if confirmed, further suggests that temperature is not a significant factor in regulating their succession. The latter would then be heavily influenced by allochthonous introductions.

In summary, the results of the PCA allowed us to summarize in one figure (Fig. 8) the seasonal occurrence patterns of 30 dominant phytoplankton species in Narragansett Bay. Although the analyses indicate that their seasonality is aligned with temperature, and represents a realistic ordination of their temporal occurrences in situ, their actual temperature preferences based on laboratory experiments appear to differ. Moreover, we have not demonstrated that week-toweek changes in dominance levels, which represent the appropriate time scale over which succession is occurring, is also regulated by temperature. This is not to say that temperature is not involved in the dynamics of succession. Rather, its role in the progression of this ecological process is most likely mediated through interactions with other environmental factors which modify species responses to thermal conditions.

Acknowledgements. Dr. David Pratt made available phytoplankton data for 1959-1963, and Dr. Betty Mitchell-Innes, Dr. Miles Furnas and Dr. Gabriel Vargo assisted with the phytoplankton counts at various times. Deborah French assisted with the computer analyses. Mrs. Blanche Coyne typed the manuscript and drafted the figures. This research was supported by NSF grants 68-1500, OCE 71-00556 and OCE 76-22563 and Department of Commerce (NOAA) Grant No. NA80RA-D00064 awarded to T. J. Smayda.

\section{LITERATURE CITED}

Allen, T. F. H., Koonce, J. F. (1973). Multivariate approaches to algal strategems and tactics in systems analysis of phytoplankton. Ecology 54: 1234-1246

Allen, T. F. H., Skagen, S. (1973). Multivariate geometry as an approach to algal community analysis. Br. phycol. J. 8: 267-287

Anderson, D. M., Morel, F. M. M. (1979). The seeding of two red tide blooms by the germination of benthic Gonyaulax tamarensis hypnocysts. Estuar. coast. mar. Sci. 8: 279-293

Baars, J. W. R. (1979). Autecological investigations on marine diatoms, 1. Experimental results in biogeographic studies. Hydrobiol. Bull. 13: 123-137

Baars, J. W. R. (1981). Autecological investigations on marine diatoms. 2. Generation times of 50 species. Hydrobiol. Bull. 15: 137-151

Blasco, D. (1971). Composicion y distribucion del fitoplancton en la region del afloramiento de las costas peruanos. Investigacíon pesq. 35: 61-112

Braarud, T. (1961). Cultivation of marine organisms as a means of understanding environmental influences on populations. In: Sears, M. (ed.) Oceanography. Am. Ass. Adv. Sci., Publ. No. 67, Washington, D.C., p. 271-298

Braarud, T. (1962). Species distribution in marine phytoplankton. J. oceanogr. Soc. Japan, 20th Ann. Vol., p. 628-649

Carpenter, E. J. (1971). Annual phytoplankton cycle of the Cape Fear River estuary, North Carolina. Chesapeake Sci. 12: $95-104$ 
Cassie, R. M. (1972). A computer programme for multivariate statistical analysis of ecological data. J. exp. mar. Biol. Ecol. 10: 207-241

Colebrook, J. M. (1982). Continuous plankton records: phytoplankton, zooplankton and environment, North-East Atlantic and North Sea, 1958-1980. Oceanol. Acta 5: 473-480

Cooley, W. W., Lohnes, P. R. (1971). Multivariate data analysis. Wiley \& Sons, Inc., N.Y.

Davis, C. O., Hollibaugh, J. T., Seibert, D. L. R., Thomas, W. H. (1980). Formation of resting spores by Leptocylindrus danicus (Bacillariophyceae) in a controlled experimental ecosystem. J. Phycol. 16: 296-302

Dixon, W. J., Brown, M. B. (1979). Biomedical computer programs P-series. Univ. Calif. Press, Berkeley

Durbin, E. (1974). Studies on the autecology of the marine diatom Thalassiosira nordenskioeldii Cleve. I. The influence of day-length, light intensity, and temperature on growth. J. Phycol. 10: 220-225

Durbin, E. (1978). Aspects of the biology of resting spores of Thalassiosira nordenskioeldii and Detonula confervacea. Mar. Biol. 45: 31-37

Eppley, R. W. (1972). Temperature and phytoplankton growth in the sea. Fish. Bull. U.S. 70: 1063-1085

Garrison, D. L. (1979). Monterey Bay phytoplankton. I. Seasonal cycles of phytoplankton assemblages. J. Plankton Res. 1: 241-265

Garrison, D. L. (1981). Monterey Bay phytoplankton. II. Resting spore cycles in coastal diatom populations. J. Plankton Res. 3: 137-156

Gauch, H. G., Jr. (1982). Noise reduction by eigenvector ordinations. Ecology 63: 1643-1649

Goldman, J. C., Ryther, J. H. (1976). Temperature-influenced species competition in mass cultures of marine phytoplankton. Biotechnol. Bioeng. 18: 1125-1144

Gran, H. H., Braarud, T. (1935). A quantitative study of the phytoplankton in the Bay of Fundy and the Gulf of Maine (including observations on hydrography, chemistry and turbidity). J. Biol. Bd Can. 1: 279-467

Hargraves, P. E., French, F. (1975). Observations on the survival of diatom resting spores. Beih. Nova Hedwigia 53: 229-239

Hollibaugh, J. T., Seibert, D. L. R., Thomas, W. H. (1981). Observations on the survival and germination of resting spores of three Chaetoceros (Bacillariophyceae) species. J. Phycol. 17: 1-9

Hulburt, E. M. (1982). The adaptation of marine phytoplankton species to nutrient and temperature. Ocean Sci. Engng 7: $187-228$

Ignatiades, L., Smayda, T. J. (1970). Autecological studies on the marine diatom Rhizosolenia fragilissima Bergon. I. The influence of light, temperature, and salinity. J. Phycol. 6: 332-339
Jeffers, J. N. R. (1967). Two case studies in the application of principal components analysis. Appl. Statist. 16: 225-236

Krawiec, R. (1982). Autecology and clonal variability of the marine centric diatom Thalassiosira rotula (Bacillariophyceae) in response to light, temperature and salinity. Mar. Biol. 69: 79-89

Levandowsky, M. (1972). An ordination of phytoplankton populations in ponds of varying salinity and temperature. Ecology 53: 398-407

Li, W. K. W. (1980). Temperature adaptation in phytoplankton: cellular and photosynthetic characteristics. In: Falkowski, P. G. (ed.) Primary productivity in the sea. Plenum Press, New York, p. 259-279

Margalef, R., Bernaldez, F. G. (1969). Grupos de especes asociadas en el fitoplancton del mar Caribe (NE de Venezuela). Investigacion Pesq. 33: 287-312

Patten, B. C., Mulford, R. A., Warinner, J. E. (1963). An annual phytoplankton cycle in lower Chesapeake Bay. Chesapeake Sci. 4: 1-20

Pratt, D. M. (1959). The phytoplankton of Narragansett Bay. Limnol. Oceanogr. 4: 425-440

Pratt, D. M. (1965). The winter-spring diatom flowering in Narragansett Bay. Limnol. Oceanogr. 10: 173-184

Smayda, T. J. (1957). Phytoplankton studies in lower Narragansett Bay. Limnol. Oceanogr. 2: 342-354

Smayda, T. J. (1969). Experimental observations on the influence of temperature, light, and salinity on cell division of the marine diatom Detonula confervacea (Cleve) Gran. J. Phycol. 5: 150-157

Smayda, T. J. (1973). The growth of Skeletonema costatum during a winter-spring bloom in Narragansett Bay, Rhode Island. Norw. J. Bot. 20: 219-247

Smayda, T. J. (1980). Phytoplankton species succession. In: Morris, I. (ed.) The physiological ecology of phytoplankton. Blackwell, Oxford, p. 493-570

Tomas, C. R. (1978a). Olisthodiscus luteus (Chrysophyceae). I. Effect of salinity and temperature on growth, motility and survival. J. Phycol. 14: 309-313

Tomas, C. R. (1978b). Olisthodiscus luteus (Chrysophyceae). II. Formation and survival of a benthic stage. J. Phycol. 14: 314-319

Tomas, C. R. (1980). Olisthodiscus luteus (Chrysophyceae). V. Its occurrence, abundance and dynamics in Narragansett Bay, Rhode Island. J. Phycol. 16: 157-166

Verity, P. (1982). Effects of temperature, irradiance and daylength on the marine diatom Leptocylindrus danicus Cleve. IV. Growth. J. exp. mar. Biol. Ecol. 60: 209-222

Watling, L., Bottom, D., Pembroke, A., Maurer, D. (1979). Seasonal variations in Delaware Bay phytoplankton community structure. Mar. Biol. 52: 207-215

Yoder, J. A. (1979). Effect of temperature on light-limited growth and chemical composition of Skeletonema costatum (Bacillariophyceae). J. Phycol. 15: 362-370 